\title{
American physicians and dual loyalty obligations in the "war on terror" Jerome Amir Singh*1,2
}

Address: ${ }^{1}$ Howard College School of Law, King George V Ave, University of Natal, Durban, 4041, South Africa and ${ }^{2}$ University of Toronto Joint Centre for Bioethics, 88 College St, Toronto, M5G 1L4, Canada

Email: Jerome Amir Singh* - singhj9@nu.ac.za

* Corresponding author

Published: 0 I August 2003

BMC Medical Ethics 2003, 4:4
Received: 18 May 2003

Accepted: 0I August 2003

This article is available from: http://www.biomedcentral.com/1472-6939/4/4

(c) 2003 Singh; licensee BioMed Central Ltd. This is an Open Access article: verbatim copying and redistribution of this article are permitted in all media for any purpose, provided this notice is preserved along with the article's original URL.

\begin{abstract}
Background: Post-September II, 200 I, the U.S. government has labeled thousands of Afghan war detainees "unlawful combatants". This label effectively deprives these detainees of the protection they would receive as "prisoners of war" under international humanitarian law. Reports have emerged that indicate that thousands of detainees being held in secret military facilities outside the United States are being subjected to questionable "stress and duress" interrogation tactics by U.S. authorities. If true, American military physicians could be inadvertently becoming complicit in detainee abuse. Moreover, the American government's openly negative views towards such detainees could result in military physicians not wanting to provide reasonable care to detainees, despite it being their ethical duty to do so.
\end{abstract}

Discussion: This paper assesses the physician's obligations to treat war detainees in the light of relevant instruments of international humanitarian law and medical ethics. It briefly outlines how detainee abuse flourished in apartheid South Africa when state physicians became morally detached from the interests of their detainee patients. I caution U.S physicians not to let the same mindset befall them. I urge the U.S. medical community to advocate for detainee rights in the U.S, regardless of the political culture the detainee emerged from. I offer recommendations to U.S physicians facing dual loyalty conflicts of interest in the "war on terror".

Summary: If U.S. physicians are faced with a conflict of interest between following national policies or international principles of humanitarian law and medical ethics, they should opt to adhere to the latter when treating war detainees. It is important for the U.S. medical community to speak out against possible detainee abuse by the U.S. government.

\section{Background}

Reports between December 2002 and March 2003 suggest that the American government is sanctioning the denial of treatment to, and torture of, terror suspects. $[1,2]$ This has drawn sharp condemnation. [3] Gregg Bloche has noted that in some quarters harm inflicted on patients is considered "ethically irrelevant" when physicians are bound by their obligations to a third party or serve the state. [4]As examples he points, inter alia, to the appearance of this argument in mainstream ethics discourse in the 1990s and to radiation experiments performed by U.S. physicians in the 1950s. According to him physicians privately justified the latter experiments in "national security" terms and relegated patient-oriented ethics to a secondary concern. The invocation of such a standpoint in the case of state-employed physicians deserves challenge. The phy- 
sician's duty of care must supercede any blanket notion of loyalty or patriotism that he or she may feel is owed to their station. If physicians are faced with a conflict of interest between following national policies or international principles of humanitarian law and medical ethics they should opt to adhere to the latter when treating war detainees.

\section{Discussion \\ Allegations of abuse}

On December 26th 2002, The Washington Post reported that hundreds of detainees who are being held in secret military facilities outside the U.S. are being subjected to questionable "stress and duress" interrogation tactics by U.S. authorities. [5] Sources interviewed by the newspaper claimed that detainees are sometimes blindfolded and "thrown into walls", bound in awkward, painful positions, subjected to loud noises, and deprived of sleep with a twenty four hour bombardment of lights. In January 2001, pictures of captured Taliban and al-Qaeda fighters released by the U.S. government showed that inmates were restrained with shackles and outfitted with blackedout goggles as they were led off the aircraft at Guantanamo Bay, Cuba. [6] According to the U.S. military, by June 2003 there had been twenty-eight suicide attempts by eighteen prisoners at Guantanamo Bay, with eighteen attempts made in 2003 alone. [7] On April 23, 2003, the U.S. government officially confirmed that children under sixteen years of age were also amongst those detained at Guantanamo Bay. [8] Since their detention, these children have been denied access to legal counsel and their parents or guardians. This is a violation of international law. [911] Age estimates of detainees are based on physical examinations by physicians. That children were detained for so long without knowledge of the international community raises questions about whether physicians who were involved in conducting the physical examinations protested the detention of these minors. The purpose of this paper though is not to focus specifically on the detention of children but on "war on terror" detainees in general.

Admittedly, the above reports cannot be considered authoritative. However, they raise salient questions about the complicity and ethical responsibility of physicians who treat patients under such conditions. I believe this merits exploration.

\section{Dual loyalty conflict defined}

In 2003 the International Dual Loyalty Working Group proposed a comprehensive set of guidelines on dual loyalty conflicts, entitled Dual Loyalty and Human Rights in Professional Practice (DLHR). [12] DLHR defines a dual loyalty as a "clinical role conflict between professional duties to a patient and obligations, express or implied, real or perceived, to the interests of a third party such as an employer, insurer or the state." This paper operates in the context of a state physician's clinical role conflict between serving his or her detainee patient and serving his or her employer (an organ of the state).

\section{How classifying captured detainees as "unlawful combatants" can give rise to conflicts of interest for the military physician}

In October 2001 there were at least 4603 physicians in the U.S. Reserves and National Guard. [13] Their breakdown was as follows: Army Reserve: 1738; Naval Reserve: 1044; Air Reserve: 754; Army National Guard: 628; and Air National Guard: 439. History has shown that physicians of the detaining power are not above being complicit in detainee abuse. [14] "Prisoner of war" status entitles detainees to basic rights under several international treaties, including the 1949 Third Geneva Convention. The American government has side-stepped these obligations by labeling many Afghan war detainees and terrorist suspects "unlawful combatants". To assess the legitimacy of this classification one must distinguish between using the words ["unlawful" combatant] to denote a concept / notion and using the term ["unlawful combatant"] to denote a distinct label.

The use of the term "unlawful combatant" to classify the above persons into a distinct category of detainees is problematic for two reasons. First, while the notion of an "unlawful" combatant is arguably recognized in international law (for example, it could be said that those who commit war crimes lose some of their protected status as they are "unlawful" combatants) this is not applicable to the Afghan detainees and other terror suspects (who have neither been charged with, nor found guilty of, war crimes). Second, the use of this particular classification as a distinct label is unrecognized in international law.

Disregard of international humanitarian law can easily lead to degrading and/or abusive treatment of detainees. This could impact negatively on the mental and physical health of detainees. The term "unlawful combatant" could potentially give rise to two disturbing possibilities: (a) detainees classified as such would arguably not be protected from questionable interrogation techniques considered unlawful in international law; [15] and (b) detaining authorities could potentially subject detainees to poor detention conditions with impunity. These scenarios could conceivably cause at least two different conflicts of interests for military physicians treating detainees classified as such.

If the detainee is being subjected to poor detention conditions or "robust interrogation" by the detaining power, state physicians could experience a conflict of interest 
between: (a) their duty to care for, and protect, a legally unprotected detainee (according to the American position) against abusive treatment (which would ideally require the physician to actively protest against, or report, such treatment to the appropriate authorities); and (b) their patriotic duty to protect and serve the interests of their country (which might arguably require the physician to remain silent about such treatment). Conversely, the American government's openly negative views towards terror suspects and the Afghan detainees could influence state physicians to not want to provide reasonable care to, or protect the interests of, such detainees. This could conceivably occur where physicians come to believe (rightly or wrongly) in the detainee's complicity or guilt in actual, inchoate, or prospective crimes against their country. This mindset could conflict with the physician's ethical duty to care for the detainee.

\section{Detainee rights in the context of ethical principles}

In their seminal work Principles of Biomedical Ethics Thomas Beauchamp and James Childress argue that a set of principles should function as an analytical framework that expresses the general values underlying rules in the common morality. [16] They have suggested that (a) respect for autonomy, (b) nonmaleficence, (c) beneficence and (d) justice should serve as guiding principles for professional ethics. Since its evocation this framework has won critical appraisal and has been widely embraced by the biomedical community. Given its centrality to the discipline of bioethics and major ethical codes I will briefly explore this framework's nature. For the purposes of this paper I will confine my discussion to the principles of nonmaleficence and beneficence.

The principle of nonmaleficence asserts an obligation not to inflict harms on others. [17] More specifically, it is a negative duty that requires actors to intentionally refrain from actions that cause harm. On the other hand, the principle of beneficence has been defined as a moral obligation to act for the benefit of others. [18] It requires agent to take positive steps to help others.

To distinguish nonmaleficence from beneficence Beauchamp and Childress have grouped them in an arrangement of four norms:

\section{Non-maleficence}

1. One ought not to inflict evil or harm.

\section{Beneficence}

2. One ought to prevent evil or harm.

3. One ought to remove evil or harm.

4. One ought to do or promote good. [19]
Moreover, Beauchamp and Childress have suggested that the rules of beneficence in their most general forms are, inter alia:

1. Protect and defend the rights of others.

2. Prevent harm from occurring to others.

3. Remove conditions that will cause harm to others. [20]

If one embraces the ethos of the above sentiments it can be argued that the principle of beneficence necessitates health professionals working in the best interests of others even when an ethical guideline or the law is silent on an issue. In this event, health professionals might be required to play roles for patients, even if such roles are not explicitly solicited in ethical guidelines or the law. A review of international ethical guidelines and international humanitarian law will illustrate instances where an advocacy role is not explicitly mandated in a relevant instrument but implicitly demanded by the principle of beneficence. Where necessary I will highlight the need for such a role and argue for its adoption by military health professionals.

\section{International humanitarian and human rights law}

"Unlawful combatant" status does not deprive detainees of basic protections required by international law and international medical ethics guidelines. A discussion of relevant instruments will illustrate this.

The international treaties governing armed conflicts are known as international humanitarian law (IHL) or the "law of war." The four Geneva Conventions of 1949 [21] establish rules for the conduct of international armed conflict. Although the U.S. has not ratified the $19771^{\text {st }}$ and $2^{\text {nd }}$ Additional Protocols of the Geneva Conventions, it ratified the four Geneva Conventions of 1949 on February 08, 1955. The Convention applies "to all cases of declared war or of any other armed conflict which may arise between two or more of the High Contracting Parties, even if the state of war is not recognized by one of them." [22]

"Common Article 3," as it has become known, is found identically in all four conventions and is taken to define a "hard core" of obligations that must be respected in all armed conflicts. This is generally taken to mean that no matter what the nature of the war or conflict certain basic rules cannot be abrogated. Common Article 3 states:

The following acts are and shall remain prohibited at any time and in any place whatsoever: violence to life and person, in particular murder of all kinds, mutilation, cruel 
treatment and torture; outrages upon personal dignity, in particular humiliating and degrading treatment.

Given that the US-led invasion of Afghanistan can undoubtedly be characterized as an "armed conflict" the Geneva Conventions should apply to persons captured during that conflict.

Article 4(2) of the 'Geneva Convention relative to the Treatment of Prisoners of War' (the "Third Geneva Convention" or "Geneva III") [23] states that members of armed forces qualify for "prisoner-of-war" status if their military organization satisfies the following four criteria: (a) that of being commanded by a person responsible for his subordinates; (b) that of having a fixed distinctive sign recognizable at a distance; (c) that of carrying arms openly; and (d) that of conducting their operations in accordance with the laws and customs of war. The U.S. government contends that al-Qaeda fighters do not meet the requirements of this definition. [24] This position can be challenged since Article 4(1) stipulates that even "militias" enjoy this status, a status that al-Qaeda fighters might arguably qualify for. Moreover, Article 5 of the Third Geneva Convention states that if there is "any doubt" as to whether captured combatants should be recognized as POWs "such persons shall enjoy the protection of the present Convention until such time as their status has been determined by a competent tribunal." In other words, if doubt exists, the status of each detainee must be determined individually, not by a blanket decision of a President (which has occurred in the case of the U.S.). Under the Geneva Conventions, "prisoner of war" (POW) status also bestows upon detainees a plethora of rights, many of which directly or indirectly involve military physicians. These include Articles 3, 13, 15, 17, 19, 21, 22, 31, and 46 . Article 17 is of particular relevance. It states that no physical or mental torture, nor any other form of coercion, may be inflicted on prisoners of war to secure from them information of any kind whatsoever. It also states that prisoners who refuse to answer questions may not be threatened, insulted, or exposed to any unpleasant or disadvantageous treatment of any kind. This would clearly rule out the application of any robust interrogation methods on detainees by a detaining power. These principles should apply to even al-Qaeda detainees.

The importance of adhering to the Geneva Convention has even been recognized by the American judiciary. In its closing, the Court in United States $v$. Noriega offered this sage observation:

[T] hose charged with that determination [Noriega's confinement, location and status], must keep in mind the importance to its own troops of faithful and, indeed, liberal adherence to the mandate of Geneva III. Regardless of how the government views this defendant as a person, the implications of a failure to adhere to the Convention are too great to justify departures. In the turbulent course of international events...the relatively obscure issues in this case may seem unimportant. They are not. The implications of a less than strict adherence to Geneva III are serious and must temper any consideration of the questions presented. [25]

According to the Body of Principles for the Protection of All Persons under Any Form of Detention or Imprisonment [26] (hereafter 'Body of Principles' or 'BOP') a "detained person" means "any person deprived of personal liberty except as a result of conviction for an offence" while an "imprisoned person" means "any person deprived of personal liberty as a result of conviction for an offence". It is thus clear that even "unlawful combatants" meet these criteria and should be entitled to the rights enumerated under this treaty. According to the BOP all persons under any form of detention or imprisonment shall be treated in a humane manner and with respect for the inherent dignity of the human person. [27] The BOP states that no person under any form of detention or imprisonment is to be subjected to torture or to "cruel, inhuman or degrading treatment or punishment". [28] This is to be interpreted so as to "extend the widest possible protection against abuses, whether physical or mental, including the holding of a detained or imprisoned person in conditions which deprive him, temporarily or permanently of the use of any of his natural senses, such as sight or hearing, or of his awareness of place and the passing of time". [29] Under this provision, no circumstance whatsoever may be invoked as a justification for "torture or other cruel, inhuman or degrading treatment or punishment". This would preclude reasons and measures geared towards safeguarding a country's "national security". Significantly, the BOP explicitly stipulates that officials who "have reason to believe that a violation of this Body of Principles has occurred or is about to occur" must report the matter to their superior authorities and, where necessary, to "other appropriate authorities or organs vested with reviewing or remedial powers". [30] Thus, military physicians need to be mindful that even "unlawful combatants" are protected against undue advantage being taken against them during interrogations. [31]

The United Nations Standard Minimum Rules for the Treatment of Prisoners [32] (hereafter U.N. Minimum Rules) make it clear that its provisions cover the general management of institutions and are applicable to all categories of prisoners, criminal or civil, untried or convicted, including prisoners subject to "security measures". [3336] Given (a) that the term "unlawful combatant" does not exist in international law, (b) that "unlawful combatants" are being detained for "security measures", and (c) 
that "unlawful combatants" detained at Guantanamo Bay and elsewhere have not, to the date of the submission of this paper, been charged, tried or convicted, it can be strongly argued that the U.N. Minimum Rules cover "unlawful combatants".

The U.S. is also acting in violation of a U.N. resolution pertaining to the protection of human rights and fundamental freedoms while countering terrorism. [37] Adopted in December 2002 this resolution affirms, among others, that States must ensure that any measure taken to combat terrorism complies with obligations under international law, in particular international human rights, refugee and humanitarian law.

The Universal Declaration of Human Rights [38] adopted by the United Nations in 1948 states that "no one shall be subjected to torture or to cruel, inhumane or degrading treatment or punishment". [39] Article 7 of the Covenant on Civil and Political Rights [40] of 1966 replicates this right word-for-word. In its General Comments, the United Nations Human Rights Committee has stated that this prohibition relates not only to "acts which cause physical pain but also to acts that cause mental suffering to victims." [41] Indefinite solitary confinement, a measure imposed on many of the terror detainees, can be seen as a form of mental suffering. The U.N. Committee has also stated no justification or extenuating circumstances excuses a violation of Article 7, including an order from a superior officer or a public authority. In 1984 the U.N. adopted the Convention Against Torture and other Cruel, Inhumane or Degrading Treatment or Punishment (hereafter Convention against Torture). [42] In Article 1 of this convention, torture is defined as "any act by which severe pain or suffering, whether physical or mental, is intentionally inflicted in order to obtain a confession, to punish or to intimidate in cases where such suffering is inflicted with the connivance of a public official." [43]

In 1978 the European Court of Human Rights ruled that the use by British forces in Northern Ireland of techniques similar to those alluded to above (hooding, forced standing, sleep deprivation, subjection to noise and deprivation of food and drink) was not torture. However, the Court did find that such methods were "inhuman and degrading," and therefore unlawful under various treaties. [44] Moreover, in 1999 the Israeli Supreme Court unanimously ruled that certain Israeli interrogation methods (including forced uncomfortable postures and sleep deprivation) was unlawful. [45] The Court also ruled that the State could not use the defense of "necessity" to justify such treatment. As such, one way or the other, if the alleged treatment meted out on Afghan war detainees and terror suspects by the U.S. is true, it is clearly considered repugnant internationally. U.S. physicians should thus not be party to such treatment. Physicians who witness such treatment have an ethical duty to speak out against it. I believe this resonates with the benevolent advocacy role for health professionals I argued for earlier.

\section{International medical ethics guidelines}

In terms of the World Medical Association (WMA) Declaration of Tokyo of 1975 (hereafter the Tokyo Declaration) [46] torture is defined as: "the deliberate, systematic or wanton infliction of physical or mental suffering by one or more persons acting alone or on the orders of any authority, to force another person to yield information, to make a confession or for any other purpose." "Any other purpose" could include simply punishing and terrorizing persons. [47] According to the Tokyo Declaration, the medical doctor should see it as a privilege to practice medicine in the service of humanity, to preserve and restore bodily and mental health without distinction as to persons, and to comfort and to ease the suffering of his or her patients. [48] Military physicians who become party to any form of abuse of detainees will be seen to have abused their positions of trust and honor.

According to the Tokyo Declaration, a physician should not "countenance, condone or participate in the practice of torture or other forms of cruel, inhuman or degrading procedures, whatever the offence of which the victim of such procedures is suspected, accused or guilty, and whatever the victim's beliefs or motives, and in all situations, including armed conflict and civil strife". [49] It states that the physician "shall not provide any premises, instruments, substances or knowledge to facilitate the practice of torture or other forms of cruel, inhuman or degrading treatment or to diminish the ability of the victim to resist such treatment". [50] Military physicians who participate in interrogation sessions, either directly, or by resuscitating unconscious detainees for the purposes of further interrogation by the detaining power, could be determined as having diminished the ability of detainees to resist such treatment. The mere presence of any military physicians during any inhumane treatment of detainees is also a violation of the Tokyo Declaration. [51]

Military physicians cannot justify their involvement in such interrogations on the basis of any political ideology (such as the U.S. government's "war on terror" or the interests of its "national security") as the Tokyo Declaration states the physician's fundamental role is to alleviate the distress of his or her fellow men, and no motive whether personal, collective or political shall prevail against this higher purpose. [52] According to DLHR the health professional should not perform medical duties or engage in medical interventions for "security purposes". [53] 
According to the Principles of Medical Ethics relevant to the Role of Health Personnel, particularly Physicians, in the Protection of Prisoners and Detainees against Torture and Other Cruel, Inhuman or Degrading Treatment or Punishment [54] (hereafter the Principles of Medical Ethics), it is a contravention of medical ethics for health personnel: (a) to apply their knowledge and skills in order to assist in the interrogation of prisoners and detainees in a manner that may adversely affect the physical or mental health or condition of such prisoners or detainees and which is not in accordance with the relevant international instruments; (b) to certify, or to participate in the certification of, the fitness of prisoners or detainees for any form of treatment or punishment that may adversely affect their physical or mental health and which is not in accordance with the relevant international instruments, or to participate in any way in the infliction of any such treatment or punishment which is not in accordance with the relevant international instruments. [55] Further, it is a gross contravention of medical ethics, as well as an offence under applicable international instruments, for health personnel to engage, actively or passively, in acts which constitute participation in, complicity in, incitement to or attempts to commit torture or other cruel, inhuman or degrading treatment or punishment. [56] It states that health personnel charged with the medical care of prisoners and detainees have a duty to provide them with protection of their physical and mental health and treatment of disease of the same quality and standard as is afforded to those who are not imprisoned or detained. [57] It also explicitly stipulates that there may be no derogation from the foregoing principles on any ground whatsoever, including public emergency. [58]

Accordingly, it is a contravention of medical ethics for health personnel to participate in any procedure for restraining a prisoner or detainee unless such a procedure is determined in accordance with "purely medical criteria" as being necessary for the protection of the physical or mental health or the safety of the prisoner or detainee himself, of his fellow prisoners or detainees, or of his guardians, and presents no hazard to his physical or mental health. [59] This is a determination that should be made by a physician. Many Afghan detainees sustained gun shot injuries prior to their capture and subsequent transportation to Guantanamo Bay. It could be strongly argued that the aforementioned shackles and blindfolds were hazardous to their health. If Afghan detainees posed no credible threat to others, and if military physicians were present when the shackling or blindfolding occurred, they should have spoken out against it. On the issue of shackling detainees the DLHR states:

The health professional should not perform any medical duties on shackled or blindfolded patients, inside or out- side the custodial setting. The only exception should be in circumstances where, in the health professional's judgment, some form of restraint is necessary for the safety of the individual, the health professional and/or others, and treatment cannot be delayed until a time when the individual no longer poses a danger. In such circumstances, the health professional may allow the minimum restraint necessary to ensure safety. [60]

In 1997 the WMA adopted the Declaration Concerning Support for Medical Doctors Refusing to Participate in, or to Condone, the Use of Torture or Other Forms of Cruel, Inhuman or Degrading Treatment [61] (The Hamburg Declaration). This declaration encourages physicians to honor their commitment to serve humanity and to resist any pressure to act contrary to the ethical principles governing their conduct. [62] The AMA Guidelines state: "A physician shall be dedicated to providing competent medical care, with compassion and respect for human dignity and rights". [63] The AMA Guidelines also state: "Physicians should help provide support for victims of torture and, whenever possible, strive to change situations in which torture is practiced or the potential for torture is great." [64]

According to the DLHR the health professional should abstain from participating, actively or passively, in any form of torture. [65] More pointedly, in its guidelines for military health professionals the DLHR states that the military health professional should refrain from direct, indirect and administrative forms of cooperation in torture and cruel, inhuman and degrading treatment and punishment at all times, including in wartime and during interrogation of prisoners. [66]

According to the DLHR the health professional passively participates by permitting his or her clinical findings or treatment to be used by authorities to aid the process of torture. Moreover, according to these guidelines, health professional should not provide any means or knowledge to facilitate the practice of torture or cruel, inhuman, or degrading treatment or punishment; and should not authorize, approve, or participate in punishment of any form, in any way, including being present when such procedures are being used or threatened. [67] According to the DLHR indirect participation includes examinations to declare an individual "fit" for caning, shackles, solitary confinement or any other type of abuse, and dietary restrictions.

The Manual on Effective Investigation and Documentation of Torture and Other Cruel, Inhumane or Degrading Treatment [68] (the Istanbul Protocol) is the first set of international guidelines intended to serve as a set of international guidelines for the assessment of persons who 
allege torture and ill treatment, for investigating cases of alleged torture, and for reporting such findings to the judiciary and any other investigative body. If physicians witness or suspect the abuse of detainees, they should consider it their ethical duty to use the Istanbul Protocol to document and report such abuse. This approach is endorsed by the DLHR. In its guidelines on prison, detention and other custodial settings the DLHR states:

The health professional should report to the custodial authorities and, where appropriate, to an independent medical authority any situation in which he or she becomes aware of allegations or evidence that those in custody are being subjected to torture or cruel, inhuman or degrading treatment. The health professional must, however, weigh this action against any reprisal or further punishment to the prisoner that may result. When appropriate, the health professional should gain the consent of the prisoner before making such a report. [69]

The DLHR makes it clear that the health professional should act in the best interests of his or her patient at all times. [70] It explicitly states that the health professional is responsible for ensuring physical and mental health care (preventive and promotive) and treatment, including specialized care when necessary; ensuring follow-up care; and facilitating continuity of care - both inside and outside of the actual custodial setting - of convicted prisoners, prisoners awaiting trial, and detainees who are held without charge/trial. The italicized provision would specifically apply to detainees held at Guantanamo Bay and other off-limit U.S. bases.

\section{Why physicians become complicit in detainee abuse: moral disengagement, ideological totalism and victim blame}

The participation of health professionals in torture (advising torturers on methods, evaluating individuals to determine whether they can survive additional torture, and using medical skills in the process of torture) is well-documented. [71] Physicians fail to denounce torture for a variety of reasons, including self-interests and self-promotion. [72] They may not wish to acknowledge that torture is perpetuated by their government, and/or their ignorance may mean that they are unaware that torture is never justifiable. [73]

There may be social circumstances and particular factors associated with the medical profession that make some of its practitioners prone to a loss of moral perspective. [74] The negative labeling or devaluing of a group by influential forces can breed a culture of ideological totalism. "Moral disengagement" occurs when subordinates of a labeling group regard the interests of the labeled group as less relevant because of the political culture under which they live. [75] Physicians must avoid morally disengaging from their patients regardless of the political culture patients emerge from. "Victim-blame" is a tendency to hold victims responsible for their own fate. If U.S. physicians knowingly or unknowingly adopt this mentality their ethical obligations towards "war on terror" detainees may become compromised. They should note that ideological totalism, moral disengagement and victim-blame were factors that facilitated the abuse of detainees in apartheid South Africa. U.S. physicians must ensure that they do not make the same mistakes when carrying out their duties in the "war on terror". The wider medical community should also guard against the same ideologies affecting their objectivity and ethical advocacy responsibilities towards detainees.

\section{The American medical community: an ethical duty to advocate for detainee rights}

In November 2002 the U.S. voted against adopting the Optional Protocol to the Convention against Torture. [76] The treaty seeks, inter alia, to establish a system of unannounced inspections of prisons and detention centers, including detention centers such as Guantanamo Bay and Bagram Base in Afghanistan (where two detainees have already died in U.S. custody). Despite strong opposition from the U.S. the United Nations General Assembly's Third Committee voted to adopt the Optional Protocol. This is a small consolation since the U.S. is under no obligation to adopt the new protocol at home. The Committee also soundly rejected, (by a margin of 98 to 11, with 37 abstentions), a U.S. amendment that would have removed funding for the treaty from the general U.N. budget and forced the parties to the protocol to shoulder its costs.

I argued earlier that the duty of beneficence sometimes necessitates the health professional adopting an advocacy role. Given that the optional protocol seeks to enhance detainee patients' rights, the U.S. medical community (and the wider medical community) should regard it as their ethical duty to pressure the U.S. government to accede to it. They should also regard it as their ethical duty to pressure the U.S. government to afford "prisoner of war" status to all Afghan detainees as the bestowing of greater rights on detainees will hopefully result in their increased protection. These measures will resonate with the health provider's beneficent duties to "promote good" and "prevent harm". They would also resonate with values enunciated in the AMA Guidelines which state: "A physician shall respect the law and also recognize a responsibility to seek changes in those requirements which are contrary to the best interests of the patient". [77] U.S. Physicians should pressure their government to realize that if the U.S. fails to respect the laws of war and detainee health rights, it cannot expect its enemies to do any better if U.S. troops are captured. 
It has been pointed out that by acting as whistleblowers, physicians can play an important role in reducing gross human rights violations. [78] When physicians stationed in military detention camps observe that detention conditions of detainees fall short of the standards required under international humanitarian law, or are of the professional opinion that such conditions are compromising, or could compromise, the health interests of detainees, the physician's duty to protect the well-being of detainees must be regarded as paramount. This view is also articulated in the AMA Guidelines which state: "A physician shall, while caring for a patient, regard responsibility to the patient as paramount." [79] According to the DLHR the health professional should recognize that passive participation, or acquiescence, in violations of a patient's human rights is a breach of loyalty to the patient. [80]

Given their incommunicado status, detainees captured in the "war on terror" are vulnerable and powerless to resist abuse. Physicians should strive to change this situation by reporting suspected violations of detainee rights to the U.N. Special Rapporteur on Torture. Alternatively, they can approach organizations such as the International Committee of the Red Cross, Medécins Sans Frontiéres, Amnesty International, Physicians for Human Rights or the Human Rights Watch. These organizations could at least use their profiles to publicize the incidents and apply pressure on the U.S. to investigate such allegations. This approach is endorsed by the American Medical Association. Its code of ethics states: "Physicians should help provide support for victims of torture and, whenever possible, strive to change situations in which torture is practiced or the potential for torture is great." [81] To discourage victimization of whistleblowers, the AMA should pressure the U.S. government to explicitly endorse its code of ethics. The AMA should also offer express support to physicians who experience, or who are likely to experience, dual loyalty conflicts. This view is supported by the DLHR which states that the health professional should support colleagues individually and collectively - through professional bodies - when the state acts to impede or threaten their ability to fulfill their duty of loyalty to patients. [82] Moreover, according to the DLHR the health professional should take advantage of opportunities for support from local, national and international professional bodies to meet their ethical and human rights duties to the patient. [83] I endorse the recommendations of the DLHR on institutional mechanisms to promote human rights in health practice.

\section{Recommendations}

If a health provider experiences a conflict of interest between the duty to care for, and protect, an arguably legally unprotected "unlawful combatant" against abusive treatment, and the patriotic duty to protect and serve the interests of one's country, he or she should consider it their legal and ethical obligation to report or actively protest against such treatment to appropriate authorities. Detainees have rights by virtue of several international legal conventions and ethical declarations. A unilateralist and isolationist mentality based on military might, selfinterest and a sense of impunity can lead to a disregard of international law, ethics and consequently, detainee rights. This mindset must be avoided by health providers. If faced with a conflict between following national policies and universally embraced multilateral principles of international law and ethics, physicians should consider themselves morally bound to follow the latter.

Conversely, even in situations where a physician comes to believe (rightly or wrongly) in the detainee's complicity or guilt in actual, inchoate or prospective crimes against the physician's country, and where the physician finds him or herself not wanting to protect the interests of a detainee because of his / her government's policies, the physician's core duty to care for the detainee patient must still prevail. Military physicians should always remember that while captured terror suspects are detainees of a government they are first and foremost patients of the physicians and are owed a duty of care. The duty of care must supercede any blanket notion of loyalty, obligation, allegiance or patriotism that the physician may feel is owed to his or her station. This view is supported by Guideline 3 of the DLHR Proposed General Guidelines for Health Professional Practice and Guideline 1 of the DLHR Guidelines for Military Health Professionals. As the DLHR points out, civilian medical ethics apply to military health professionals as they do to civilian practitioners. [84]

Whereas the gloves have seemingly come off in the "war on terror" physicians involved in the war should practice ethics-based medicine and keep theirs on.

\section{Summary}

"Unlawful combatant" detainees have rights by virtue of several international legal conventions and ethical declarations. Ideological totalism, moral disengagement and victim-blame can facilitate the abuse of detainees and this mindset must be avoided by state physicians. Physicians should report suspected violations of detainee rights to the U.N. Special Rapporteur on Torture or organizations such as the International Committee of the Red Cross, Medécins Sans Frontiéres, Amnesty International, Physicians for Human Rights or the Human Rights Watch. To discourage victimization of physician whistleblowers of detainee abuse, the AMA should pressure the U.S. government to explicitly endorse its code of ethics. The U.S. medical community should regard it as their ethical duty to pressure their government to accede to the Optional Protocol to the Convention against Torture. They should also 
regard it as their ethical duty to pressure the U.S. government to afford "prisoner of war" status to all Afghan detainees. If faced with a conflict between following national policies or universally accepted multilateral principles of international law and ethics, state physicians should consider themselves ethically bound to follow the latter. The duty of care must supercede any blanket notion of loyalty, obligation, allegiance or patriotism that the physician may feel is owed to his or her station.

\section{Competing interests}

None declared.

\section{Acknowledegements}

The author wishes to thank Peter A. Singer, Douglas Martin, Trudo Lemmens, Dena Taylor, Bernard Dickens, Alan Dodson, and the paper's reviewers for their feedback on earlier drafts of this work.

\section{References}

I. Gall C: U.S. military investigating death of Afghan in custody. The New York Times . 2003 March 04

2. Priest $D$ and Gellman $B$ : U.S. decries abuse but defends interrogations. The Washington Post . 2002 December 26

3. Summerfield D: Fighting "terrorism" with torture. BMJ 2003, 326:773.

4. Gregg Bloche M: Clinical loyalties and the social purposes of medicine. JAMA 1999, 28 I:268-274.

5. Priest $D$ and Gellman $B$ : U.S. decries abuse but defends interrogations. The Washington Post . 2002 December 26

6. U.S. sedates terror suspects [http://news.bbc.co.uk///hi/world/ americas/ /772522.stm]. January 2I, 2002

7. Griffiths F: Guantanamo prisoner attempts suicide. [http:// www.guardian.co.uk/worldlatest/story/0,1280,-2747985,00.html]. June 4, 2003

8. U.S. detains children at Guantanamo Bay [http://www.guard ian.co.uk/international/story/0,3604,94/875,00.html]. April 23, 2003

9. Article 40. Convention on the Rights of the Child [http:// www.savethechildren.ca/en/whoweare/whounrights.html]. G.A. res. 44/25, annex, 44 U.N. GAOR (Supp. (No. 49) at I67, U.N. Doc. A/44/ 49 (1989), entered into force Sept.2 1990

10. United Nations Standard Minimum Rules for the Administration of Juvenile Justice ("The Beijing Rules") [http:// www.unhchr.ch/html/menu3/b/h comp48.htm]. G.A. res. 40/33, annex, 40 U.N. GAOR Supp. (No. 53) at 207, U.N. Doc. A/40/53 (1985)

II. United Nations Rules for the Protection of Juveniles Deprived of their Liberty [http://193.194.138.190/html/menu3/b/ h comp37.htm]. G.A. res. 45/II 3, annex, 45 U.N. GAOR Supp. (No. 49A) at 205, U.N. Doc. A/45/49(1990)

12. Physicians for Human Rights and University of Cape Town Health Sciences Faculty: Dual loyalty and human rights in health professional practice: proposed guidelines and institutional standards. Boston: Physicians for Human Rights [http:// www.phrusa.org/healthrights/dual loyalty.html]. Accessed July 2003

13. Albert T: Physicians prepare for duty in military. [http:// www.ama-assn.org/sci-pubs/amnews/pick 0l/prsal015.htm]. October $15,200 \mid$

14. British Medical Association: The Medical Profession and Human Rights: Handbook For a Changing Agenda. London $200 \mathrm{I}$.

15. Article 17, paragraph 3 of the Third Geneva Convention [http://193.194.138.190/html/menu3/b/91.htm]

16. Beauchamp $T$ and Childress J: Principles of Biomedical Ethics. New York: Oxford University Press Fifth200I.

17. Beauchamp T and Childress J: Principles of Biomedical Ethics. New York: Oxford University Press Fifth200 I:I I3.

18. Beauchamp T and Childress J: Principles of Biomedical Ethics. New York: Oxford University Press Fifth2001:166.

19. Beauchamp T and Childress J: Principles of Biomedical Ethics. New York: Oxford University Press Fifth200 I:I I5.
20. Beauchamp $T$ and Childress J: Principles of Biomedical Ethics. New York: Oxford University Press Fifth2001:167.

21. The Geneva Convention of 27 July 1929 relative to the treatment of prisoners of war, as amended in 1949 [http:// www.icrc.org/|HL.nsf/52d68d|4de6/60e0c/2563da005fdb/b/ eb/57/b00daec90ec/2564/ e00402aa6? OpenDocument]

22. Article 2. The Geneva Convention of 27 July 1929 relative to the treatment of prisoners of war, as amended in 1949 [http:l /www.icrc.org//HL.nsf/52d68d I4de6/60e0c/2563da005fdblb/ eb/57/b00daec90ec/2564le00402aa6? OpenDocument]

23. Geneva Convention relative to the Treatment of Prisoners of War (also known as the Third Geneva Convention) [http:/ /www.hri.ca/uninfo/treaties/92.shtml]. Adopted on 12 August 1949 by the Diplomatic Conference for the Establishment of International Conventions for the Protection of Victims of War, held in Geneva from 2I April to 12 August, 1949. Entry into force 21 October 1950.

24. Geneva Convention to cover Taliban [http://news.bbc.co.uk/I/ hi/world/americas/I775162.stm]. January 22, 2002

25. United States v Noriega 746 F. Supp 1506 (S.D.FI. 1990) at 808 F.Supp at 803 [http://www.law.emory.edu/I I circuit/july97/924687.man.html]

26. Body Principles for the Protection of All Persons under Any Form of Detention or Imprisonment. General Assembly resolution 43/173 of 9 December 1988 [http://www.nchre.org/ readingroom/undocuments/bpil.shtml]

27. Principle I, Body Principles for the Protection of All Persons under Any Form of Detention or Imprisonment. General Assembly resolution $43 / 173$ of 9 December 1988 [http:// www.nchre.org/readingroom/undocuments/bpil.shtml]

28. Principle 6. Body Principles for the Protection of All Persons under Any Form of Detention or Imprisonment. General Assembly resolution 43/173 of 9 December 1988 [http:// www.nchre.org/readingroom/undocuments/bpil.shtml]

29. Principle 6. Body Principles for the Protection of All Persons under Any Form of Detention or Imprisonment. General Assembly resolution 43/173 of 9 December 1988 [http:// www.nchre.org/readingroom/undocuments/bpil.shtml]

30. Principle 7(2). Body Principles for the Protection of All Persons under Any Form of Detention or Imprisonment. General Assembly resolution 43/I73 of 9 December 1988 [http:// www.nchre.org/readingroom/undocuments/bpil.shtml]

31. Article 21. Body Principles for the Protection of All Persons under Any Form of Detention or Imprisonment. General Assembly resolution $43 / 173$ of 9 December 1988 [http:// www.nchre.org/readingroom/undocuments/bpil.shtml]

32. The First United Nations Congress on the Prevention of Crime and the Treatment of Offenders Geneva 1955 [http:// 193.194.138.190/html/menu3/b/h comp34.htm].

33. Article 4(I), The First United Nations Congress on the Prevention of Crime and the Treatment of Offenders Geneva 1955 [http://193.194.138.190/html/menu3/b/h comp34.htm].

34. Article 84 (I), The First United Nations Congress on the Prevention of Crime and the Treatment of Offenders Geneva 1955 [http://193.194.138.190/html/menu3/b/h comp34.htm].

35. Article 84(2), The First United Nations Congress on the Prevention of Crime and the Treatment of Offenders Geneva 1955 [http://193.194.138.190/html/menu3/b/h comp34.htm].

36. Article 95, The First United Nations Congress on the Prevention of Crime and the Treatment of Offenders Geneva 1955 [http://193.194.138.190/html/menu3/b/h comp34.htm].

37. General Assembly Resolution A/RES/57/219 of 16 December 2002 on the Protection of Human Rights and Fundamental Freedoms while Countering Terrorism [http://www.hri.cal fortherecord2002/documentation/genassembly/a-res-57-219.htm]

38. United Nations General Assembly resolution 217 A (III) of 10 December 1948 [http://www.un.org/Overview/rights.html]

39. Article 5, United Nations General Assembly resolution 217 A (III) of 10 December 1948 [http://www.un.org/Overview/ rights.html]

40. International covenaut on civil and political rights. Adopted and opened for signature, ratification and accession by United Nations General Assembly resolution 2200A (XXI) of 16 December 1966 [http://www.iidh.ed.cr/docweb/instrumen tos/ing/ pacto\%20internacional\%20de\%20devechos\%20civiles\%20y\%20politic s.htm]. Entry into force 23 March 1976 
4I. Kellberg L: Torture: International Rules and Procedures. In: An End to Torture: Strategies for its Eradication Edited by: Duner B. London: Zen Books; 1998.

42. Convention against Torture and Other Cruel, Inhuman or Degrading Treatment or Punishment. Adopted and opened for signature, ratification and accession by General Assembly resolution 39/46 of I0 December 1984 [http://www.unh chr.ch/html/menu3/b/h cat39.htm]. Entered into force 26 June 1987

43. Article I of both Declarations, Convention against Torture and Other Cruel, Inhuman or Degrading Treatment or Punishment. Adopted and opened for signature, ratification and accession by General Assembly resolution $39 / 46$ of 10 December $1984 \quad$ [http://www.unhchr.ch/html/menu3/b/ h cat39.htm]

44. Ireland v UK (1978) 2 EHRR 25 paragraph 168 [http:// www.law.qub.ac.uk/humanrts/ehris/ni/icase/intcaseA.htm]

45. Israel Supreme Court; Public Committee against Torture in Israel v. the State of Israel. 1999.

46. The 29th World Medical Assembly, Tokyo, Japan, October 1975 [http://www.cirp.org/library/ethics/tokyo/]

47. McQuoid-Mason DJ and Dada MA: Guide to Forensic Medicine and Medical Law. Durban: Independent Medico-Legal Unit 1999.

48. Paragraph I, preamble of the 29th World Medical Assembly, Tokyo, Japan, October 1975 [http://www.cirp.org/library/ethics/ tokyo/]

49. Article I, the Declaration of Tokyo [http://www.euroethics.de/ tokyo.htm]

50. Article 2, the Declaration of Tokyo [http://www.euroethics.de/ tokyo.htm]

51. Article 3, the Declaration of Tokyo [http://www.euroethics.de/ tokyo.htm]

52. Article 4, the Declaration of Tokyo [http://www.euroethics.de/ tokyo.htm]

53. Guideline I4. DLHR Guidelines on Prison, Detention and other Custodial Settings [http://phrusa.org/healthrights/ dl 4.html\#a]

54. General Assembly resolution 37/194 of I8 December 1982 [http://www.un.org/documents/ga/res/37/a37r/94.htm]

55. Principle 4, General Assembly resolution 37/194 of 18 December 1982 [http://www.un.org/documents/ga/res/37/ a37r194.htm]

56. Principle 2, General Assembly resolution 37/194 of 18 December 1982 [http://www.un.org/documents/ga/res/37/ a37r194.htm]

57. Principle I, General Assembly resolution 37/194 of 18 December 1982 [http://www.un.org/documents/ga/res/37/ a37r 194.htm]

58. Principle 6, General Assembly resolution 37/194 of 18

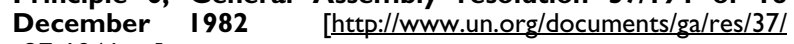
a37r 194.htm]

59. Principle 5, General Assembly resolution 37/194 of 18

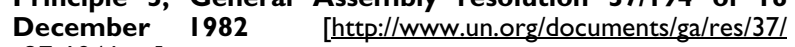
a37r194.htm]

60. Guideline I3. DLHR Guidelines on Prison, Detention and other Custodial Settings [http://phrusa.org/healthrights/ dl 4.html\#a]

61. The 49th WMA General Assembly. Hamburg, Germany, November 1997 [http://www.wma.net/e/policy/a /2.htm]

62. Article 4(I), The 49th WMA General Assembly. Hamburg, Germany, November 1997 [http://www.wma.net/e/policyl a | 2.htm]

63. Principle I, The 49th WMA General Assembly. Hamburg, Germany, November 1997 [http://www.wma.net/e/policy/ a I 2.htm]

64. AMA Code of Ethics (Professionalism) E-2.067 Torture [http://www.ama-assn.org/ama/pub/category/8421.html]. Issued December 1999

65. Guideline 8. DLHR Guidelines on Prison, Detention and other Custodial Settings [http://phrusa.org/healthrights/ dl 4.html\#a]

66. Guideline 7. DLHR Guidelines for Military Health Professionals [http://phrusa.org/healthrights/dl 4.html\#e]

67. Guideline 9. DLHR Guidelines on Prison, Detention and other Custodial Settings [http://phrusa.org/healthrights/ dl $4 . \mathrm{html} \#$ a]
68. Manual on the Effective Investigation and Documentation of Torture and Other Cruel, Inhuman or Degrading Treatment or Punishment [http://www.phrusa.org/research/ istanbul protocol/ist prot.pdf]

69. Guideline 6. DLHR Guidelines on Prison, Detention and other Custodial Settings [http://phrusa.org/healthrights/ dl 4.html\#a]

70. Guideline I, DLHR Guidelines on Prison, Detention and other Custodial Settings [http://phrusa.org/healthrights/ dl 4.html\#a]

7I. Stover E, Nightingale EO and eds: The Breaking of Bodies and Minds. New York: WH Freeman and Co 1985

72. British Medical Association: BMA Guidance medical treatment: Guidance for decision making. London: BMJ Books 1999:81.

73. British Medical Association: Withholding and withdrawing lifeprolonging medical treatment: Guidance for decision making. London: $B M J$ Books 1999:8I-2.

74. Weinstein H: Psychiatry and the CIA: Victims of Mind Control. Washington: American Psychiatric Press Inc 1988.

75. British Medical Association: The Medical Profession and Human Rights: Handbook For a Changing Agenda. London 200 I:xxiii.

76. Economic and Social Council Resolution 2002/27 [http:// wwwl.umn.edu/humanrts/instree/optprotort.html]

77. Principle 3; Principles of Medical Ethics, AMA [http:// www.ama-assn.org/ama/upload $/ \mathrm{mm} / 369 /$ principlestracked.pdf]

78. British Medical Association: The Medical Profession and Human Rights: Handbook For a Changing Agenda. London 200 I:xxiii.

79. Principle 8, Principles of Medical Ethics, AMA [http:// www.ama-assn.org/ama/upload $/ \mathrm{mm} / 369 /$ principlestracked.pdf

80. Guideline 6. DLHR Proposed General Guidelines for Health Professional Practice [http://phrusa.org/healthrights/dl 4.html\#c]

81. AMA Code of Ethics (Professionalism) E-2.067 Torture [http://www.ama-assn.org/ama/pub/category/8421.html]. Issued December 1999

82. Guideline I4. DLHR Proposed General Guidelines for Health Professional Practice [http://phrusa.org/healthrights/dl 4.html\#d]

83. Guideline I I. DLHR Proposed General Guidelines for Health Professional Practice [http://phrusa.org/healthrights/dl 4.html\#d]

84. Guideline 2. DLHR Guidelines for Military Health Professionals [http://phrusa.org/healthrights/dl 4.html\#e]

\section{Pre-publication history}

The pre-publication history for this paper can be accessed here:

http://www.biomedcentral.com/1472-6939/4/4/prepub

Publish with Biomed Central and every scientist can read your work free of charge

"BioMed Central will be the most significant development for disseminating the results of biomedical research in our lifetime. "

Sir Paul Nurse, Cancer Research UK

Your research papers will be:

- available free of charge to the entire biomedical community

- peer reviewed and published immediately upon acceptance

- cited in PubMed and archived on PubMed Central

- yours - you keep the copyright 